\title{
The Use of $\mathrm{Al}, \mathrm{Cu}$, and $\mathrm{Fe}$ in an Integrated Electrocoagulation-Ozonation Process
}

\author{
Carlos E. Barrera Díaz and Nelly González-Rivas \\ Centro Conjunto de Investigación en Química Sustentable, Facultad de Química, \\ Universidad Autónoma del Estado de México, km 14.5, Carretera, 50200 Toluca-Atlacomulco, MEX, Mexico \\ Correspondence should be addressed to Carlos E. Barrera Díaz; cbd0044@yahoo.com
}

Received 23 April 2015; Accepted 5 July 2015

Academic Editor: Nadjib Drouiche

Copyright ( 2015 C. E. Barrera Díaz and N. González-Rivas. This is an open access article distributed under the Creative Commons Attribution License, which permits unrestricted use, distribution, and reproduction in any medium, provided the original work is properly cited.

\begin{abstract}
This study presents the effect of supplying electrochemically generated metallic ions ( $\mathrm{Al}, \mathrm{Cu}$, and $\mathrm{Fe})$ during an ozonation process for treating industrial wastewater. The pollutant removal efficiencies of the electrocoagulation (EC), ozonation, and coupled ECozonation processes were examined by the decrease in chemical oxygen demand (COD) as a function of treatment time. The EC was performed in a raw industrial wastewater, which has contributions from 39 chemical, 34 metal finishing, 22 textile, 11 leather, and 5 automotive plants, at $\mathrm{pH}$ (7.3) using a current density of $150 \mathrm{~A} / \mathrm{m}^{2}$ for $60 \mathrm{~min}$, giving a $45 \%$ reduction in COD. The ozonation process was more effective with the same wastewater, reducing the COD by $52 \%$ after 60 min of treatment. Combining the EC and ozonation methods resulted in a synergistic process that improves the reduction of COD in a shorter time. In just 12 min the integrated process reduced the COD by $88 \%$. Thus, the combination of EC and ozonation processes improves noticeably the wastewater quality, decreasing the treatment time and also reducing the sludge production.
\end{abstract}

\section{Introduction}

Electrochemical treatment techniques are a real alternative for treating wastewater, since the system configuration is quite simple. The electrochemical cells are easy to operate and in many cases there are several reactions that take place in situ which minimize the chemical supply into the system. In fact, the main reagent is the electron, which is considered a clean reagent. Thus, the sludge generation is significantly reduced [1-5].

In EC the cathodic and anodic reactions are used to produce coagulants in situ, which destabilize the colloidal particles. In wastewater, colloidal particles are negatively charged (typically -40 to $-20 \mathrm{mV}$ ) with the surrounding positive ions forming a double electric layer; therefore colloidal particles repel each other, preventing contact. Therefore, the main aim of this process is to destabilize the colloids using the generated in situ coagulants, so the particles can aggregate forming "flocs" and then these flocs precipitate and sediment and could be separated from the aqueous solution [6-10].
From the technological point of view, the principal variation from chemical coagulation is that the external dosing is eliminated, since the metal cations are produced in situ. However, there are some other advantages such that particle settling is faster and sludge generation is decreased [11-13]. Sometimes some chemicals are required, for example, a supporting electrolyte is added when the conductivity of the solution is too low.

There are two principal anodic reactions: one is related to the metal oxidation ( $\mathrm{Fe}, \mathrm{Al}, \mathrm{Zn}$, or $\mathrm{Cu}$ ) which leads to the metal dissolution into aqueous solution (Reaction (1)) and the other one is the water oxidation (Reaction (2)):

$$
\begin{aligned}
& \text { Metal } \longrightarrow \text { Oxidized Metal }+e^{-} \\
& 2 \mathrm{H}_{2} \mathrm{O} \longrightarrow \mathrm{O}_{2(\mathrm{~g})}+4 \mathrm{H}^{+}+4 e^{-}
\end{aligned}
$$

In the case of cathodic reaction, regardless of metal, water reduction is the main reaction (Reaction (3)). The produced hydroxyl ions react in the bulk solution with metal cations 
to form insoluble species, whereas the $\mathrm{H}_{2}$ leaves the system [14-16]:

$$
2 \mathrm{H}_{2} \mathrm{O} \longrightarrow \mathrm{OH}^{-}+4 \mathrm{H}_{2}(\mathrm{~g})
$$

On the other hand, ozonation is a well-known technology for wastewater treatment. This process presents advantages, such as removal of color and odor and diminishing of COD and Total Organic Carbon (TOC). However, the gas-liquid phase mass transfer limits its efficiency. Ozone oxidizes organic pollutants by direct oxidation with ozone molecules or by the generation of ${ }^{\bullet} \mathrm{OH}$ radicals, which are powerful oxidizing agents $[17,18]$.

Recently, many efforts have been made to increase the potential of EC as reliable pollutant removal technology by the synergistic combination with other treatment procedures [19-21]. Thus, the main aim of this work is to present some physicochemical aspects of the coupled EC-ozonation process; it is also demonstrated that, using this join method, the treatment time is reduced as compared with the sole application of EC or ozone.

\section{Materials and Methods}

2.1. Wastewater Samples. Industrial wastewater was used in the EC, ozone, and combined EC-ozonation processes. The wastewater was collected from a treatment plant, which receives water discharges of 144 different industries. The wastewater contribution is mainly by 39 chemical, 34 metal finishing, 22 textile, 11 leather, and 5 automotive plants. For the collection, a set of samples were introduced in plastic containers, labeled, and then refrigerated. Finally, they were transported to university laboratory.

2.2. Electrocoagulation Reactor. The EC process was carried out using an electrochemical reactor operating in batch mode. The reactor consists of a vessel with capacity of $1.0 \mathrm{~L}$ but only $0.8 \mathrm{~L}$ was used in all trials. The corresponding experiments were carried out with an arrangement of two parallel monopolar electrodes made of aluminum, copper or iron. Each electrode was $5.0 \times 4.0 \mathrm{~cm}$ with a surface area of $20 \mathrm{~cm}^{2}$. For providing the current density of $150 \mathrm{~A} / \mathrm{m}^{2}$ a DC power source was supplied to the system as previously reported [22]. Samples were taken at regular intervals to determine COD.

2.3. Ozone Reactor. The ozonation was carried out using a $1.0 \mathrm{~L}$ glass reactor, although only $0.8 \mathrm{~L}$ of wastewater was used for the reaction. Ozone was introduced into the reactor through a porous plate situated at the reactor bottom. The ozone was generated using a flow rate of $60 \mathrm{~mL} / \mathrm{min}$ and pressure of 3 psi by a Pacific Ozone Technology generator model number LAB212, 10 SCFH-AIR-STP. The ozone concentration at the inlet and outlet gas of the reactor was measured by $0.1 \mathrm{M}$ potassium iodide titration method [23]. Samples were taken at regular intervals to determine COD.

2.4. Coupled Electrochemical-Ozone Process. The metal electrodes (consisting of an array of 2 parallel monopolar

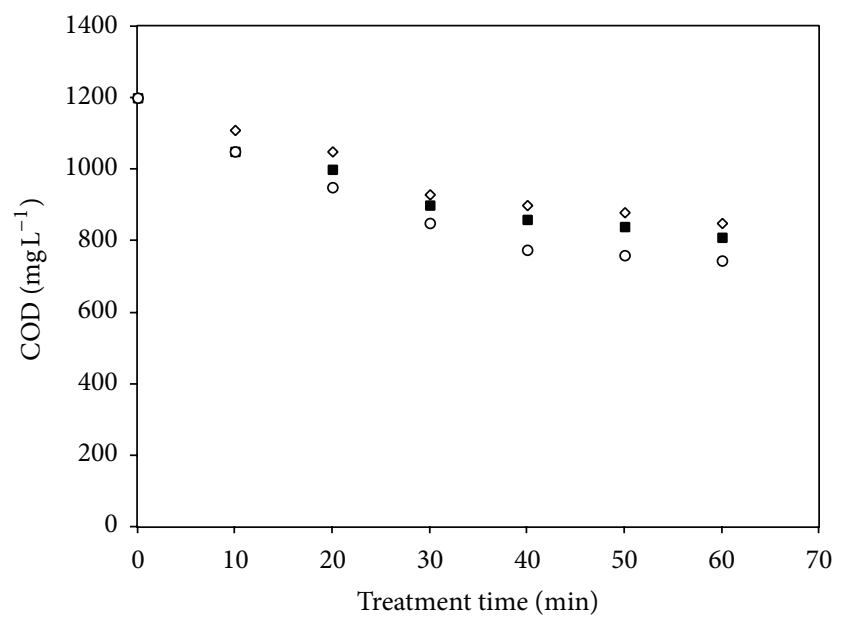

Figure 1: COD abatement as a function of treatment time using $(\diamond)$ $\mathrm{Fe},(\mathbf{\square}) \mathrm{Cu}$, and (o) $\mathrm{Al}$ anode materials. The initial $\mathrm{pH}$ was 7.3 .

electrodes) were installed inside the ozonation reactor. The treatment was carried out using $0.8 \mathrm{~L}$ of wastewater. Ozone was supplied on the bottom of the reactor and the $150 \mathrm{~A} / \mathrm{m}^{2}$ current density for the electrodes was provided from the DC power source. Samples were taken at regular intervals to measure COD.

2.5. Methods of Analysis. The pollutant removal efficiencies of the EC, ozonation, and coupled EC-ozonation processes were determined by the reduction of COD. This parameter was determined by the open reflux method of the American Public Health Association (APHA) [23], which involves the refluxing of sample with potassium dichromate and sulfuric acid for $2 \mathrm{~h}$. Prior to the test, samples were centrifuged at $10,000 \mathrm{rpm}$ for $15 \mathrm{~min}$ to remove any suspended particles. All measurements were done in duplicate and the plotted values represent the average of the results. The estimated errors are within $2 \%$.

2.6. Chemical Distribution Species Diagrams. In order to calculate and elaborate the aluminum, copper, and iron species diagrams as a function of $\mathrm{pH}$ the MEDUSA program was used [24]. These diagrams are presented in Figure 2.

\section{Results and Discussion}

3.1. Electrocoagulation. Figure 1 shows the COD removal as a function of EC treatment time, using three different anodes $(\mathrm{Al}, \mathrm{Cu}$, and $\mathrm{Fe})$. As it is observed, the maximum removal is achieved by using $\mathrm{Al}$ electrodes, whereas a similar behavior is observed for $\mathrm{Fe}$ and $\mathrm{Cu}$ electrodes. EC relies on the floc formation by the in situ anode dissolution. The production of hydroxyl anions due to water reduction reaction in the cathode produces an increment in the $\mathrm{pH}$ of the solution. Both electrodic reactions result in the formation of insoluble compounds, which precipitates removing the pollutant from aqueous solution. 

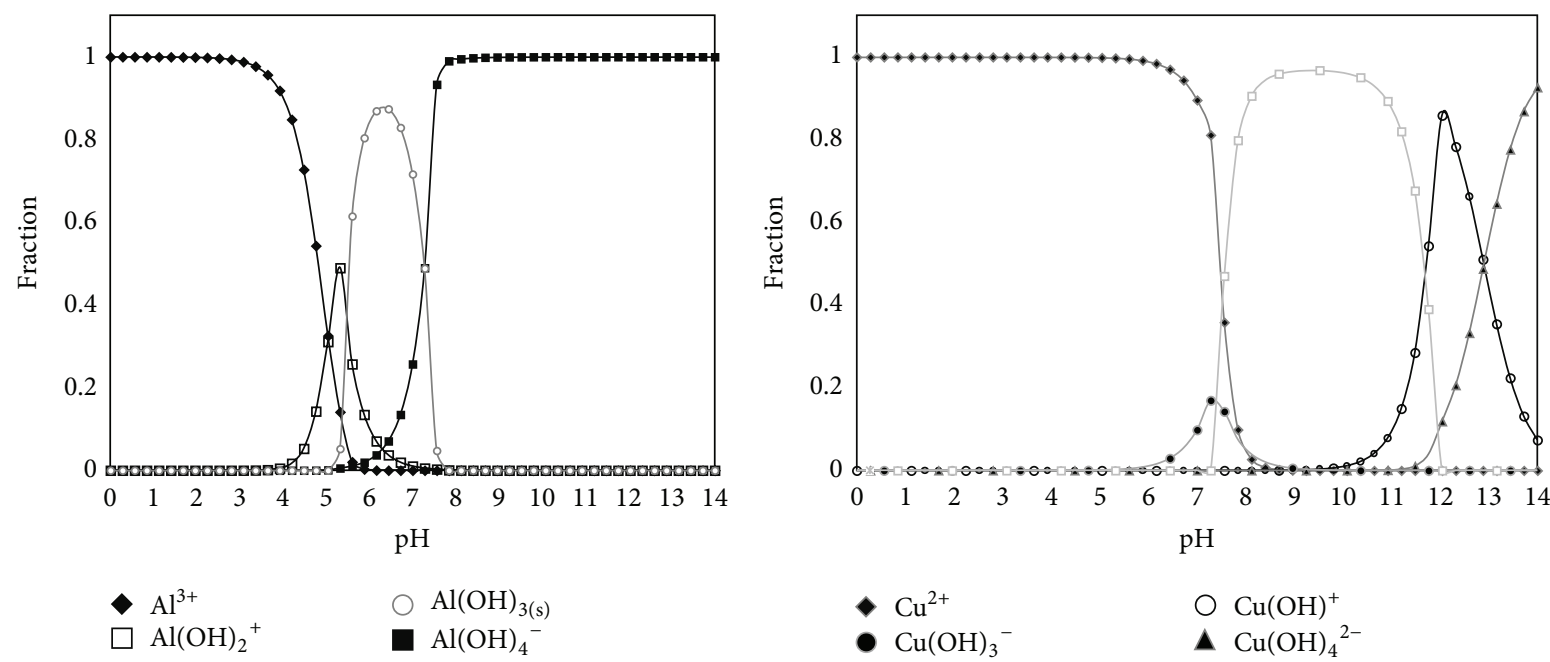

$\begin{array}{ll}\bullet \mathrm{Al}^{3+} & \bigcirc \mathrm{Al}(\mathrm{OH})_{3(\mathrm{~s})} \\ \square \mathrm{Al}(\mathrm{OH})_{2}{ }^{+} & \mathbf{A l}(\mathrm{OH})_{4}^{-}\end{array}$

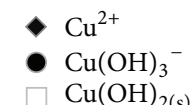

$\mathrm{O} \mathrm{Cu}(\mathrm{OH})^{+}$

$\mathrm{Cu}(\mathrm{OH})_{2(\mathrm{~s})}$

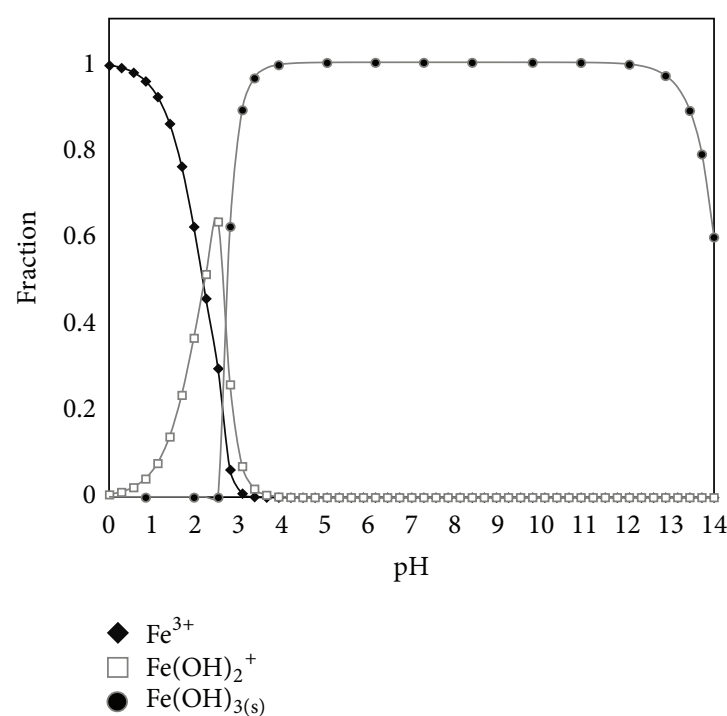

Figure 2: Chemical species diagram for $\mathrm{Al}, \mathrm{Cu}$, and $\mathrm{Fe}$ in aqueous solution as a function of $\mathrm{pH}$. These diagrams were obtained using the MEDUSA program.

The chemical species distribution obtained using the MEDUSA program for the three cations is presented in Figure 2. From Figure 2 it can be observed that in the three cases at acidic conditions free cations, that is, $\mathrm{Al}^{3+}, \mathrm{Cu}^{2+}$, and $\mathrm{Fe}^{3+}$, are the predominant species. However, once the $\mathrm{pH}$ increases hydroxo complexes start to form and under neutral conditions the insoluble species are obtained. Note that the initial wastewater was 7.3; at this condition the $\mathrm{Cu}$ is still as cation, whereas the $\mathrm{Al}$ and Fe are already forming hydro complexes. EC removes the pollutants due to the charge neutralization of the colloids present in the system and also by pollutant attraction due to electrostatic forces to the insoluble metal species [25]. The efficiency of EC is directly related to the amount of pollutants present in wastewater [26]. However, the remaining COD present in the system indicates that there are dissolved pollutants, which cannot be removed using this method. Thus, it required a coupled system which increases the pollutant removal rate.
3.2. Ozone. The ozone effect on the COD reduction into wastewater is presented in Figure 3. As it is shown, there is only a reduction of about $50 \%$ after one hour of treatment.

The behavior in the reduction of COD can be attributed to the decomposition of ozone in water to form hydroxyl radicals, which occurs as described in [27]

$$
\begin{gathered}
\mathrm{O}_{3}+\mathrm{OH}^{-} \longrightarrow \mathrm{O}_{2}+\mathrm{HO}_{2}^{-} \\
\mathrm{O}_{3}+\mathrm{HO}_{2}^{-} \longrightarrow \mathrm{HO}_{2}{ }^{-}+\mathrm{O}_{3}^{\cdot-} \\
\mathrm{HO}_{2}{ }^{--} \\
\mathrm{O}_{2}^{+}+\mathrm{O}_{2}^{\cdot-}+\mathrm{O}_{3} \longrightarrow \mathrm{O}_{2}+\mathrm{O}_{3}^{\cdot-} \\
\mathrm{O}_{3}^{\cdot-}+\mathrm{H}^{+} \longrightarrow \mathrm{HO}_{3}^{\bullet} \\
\mathrm{HO}_{3}^{\cdot} \longrightarrow \mathrm{OH}^{\bullet}+\mathrm{O}_{2}
\end{gathered}
$$


TABLE 1: Pollutant removal efficiency with a combined process is applied.

\begin{tabular}{|c|c|c|c|}
\hline Pollutant & Electrode type and ozone flow rate & Removal efficiency & Ref. \\
\hline Distillery effluent & Iron electrodes, $15 \mathrm{~mL} \mathrm{O}_{3} \mathrm{~min}^{-1}$ & $83 \%$ COD, $100 \%$ color & [31] \\
\hline Industrial wastewater & Iron electrodes, $23 \mathrm{~mL} \mathrm{O}_{3} \mathrm{~min}^{-1}$ & $63 \%$ COD, $90 \%$ turbidity & {$[18]$} \\
\hline Boat pressure washing wastewater & Iron and aluminium electrodes, $10 \mathrm{~mL} \mathrm{O}_{3} \mathrm{~min}^{-1}$ & $88 \%$ TOC, $76 \%$ COD & [32] \\
\hline Reactive blue & Iron electrodes, $20 \mathrm{~mL} \mathrm{O}_{3} \mathrm{~min}^{-1}$ & $80 \%$ TOC, $96 \%$ color & [33] \\
\hline Reactive black & Iron electrodes, $20 \mathrm{~mL} \mathrm{O}_{3} \mathrm{~min}^{-1}$ & $60 \%$ COD, $94 \%$ color & {$[34]$} \\
\hline Reactive yellow & Iron electrodes, $20 \mathrm{~mL} \mathrm{O}_{3} \mathrm{~min}^{-1}$ & $85 \%$ TOC, $100 \%$ color & [35] \\
\hline
\end{tabular}

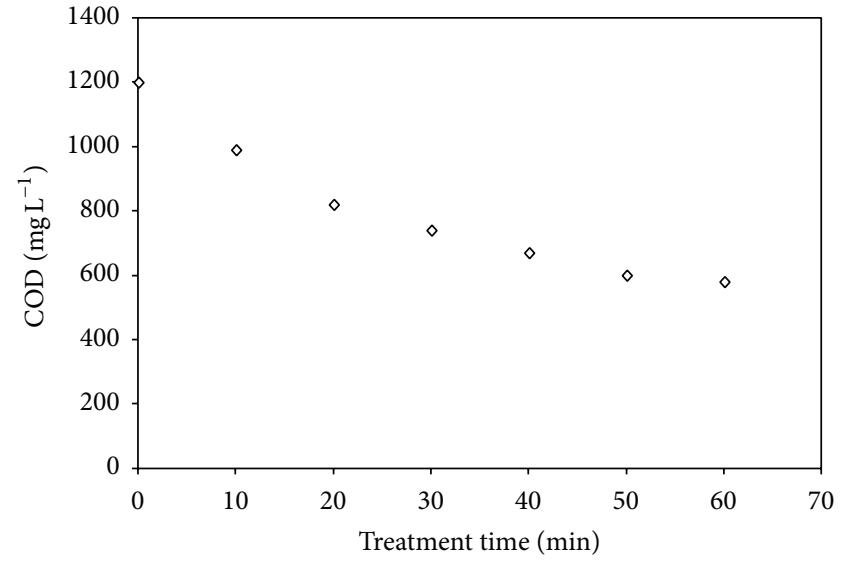

FIGURE 3: COD abatement as a function of treatment time using ozone. The initial $\mathrm{pH}$ was 7.3 .

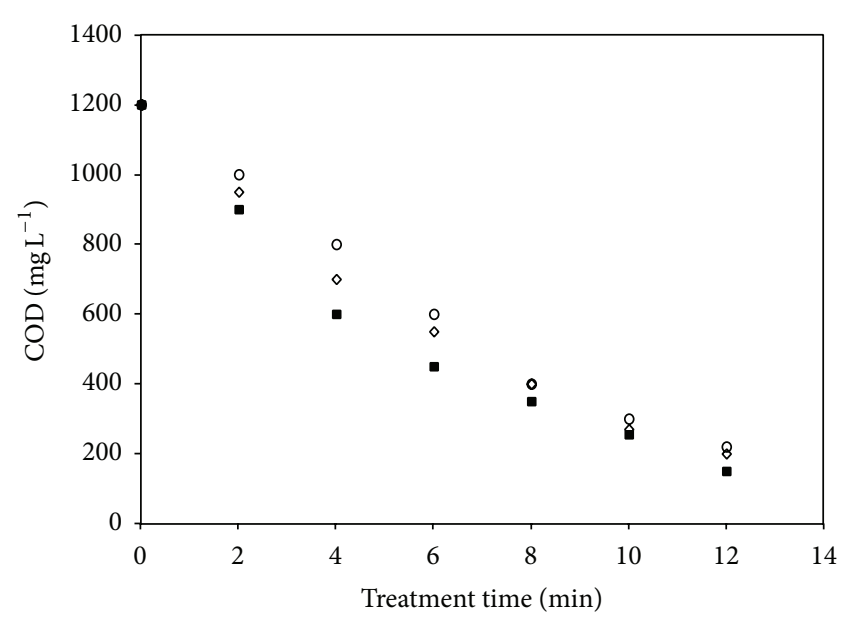

Figure 4: COD abatement as a function of treatment time when the coupled EC-ozonation process is used, and $(\diamond) \mathrm{Fe},(\mathbf{\square}) \mathrm{Cu}$, and (o) $\mathrm{Al}$ anode materials are employed. The initial $\mathrm{pH}$ was 7.3 .

It is noticeable that the generation of hydroxyl radicals is limited by the amount of ozone introduced into the system, but the mass transfer of the ozone from the gas to the liquid phase also affects this process.

3.3. Electrocoagulation-Ozonation. Figure 4 presents the pollutant removal when the coupled electrochemical-ozone is applied to wastewater. As can be observed, a faster and efficient removal is obtained. Since in EC the COD removal was around $45 \%$ in $60 \mathrm{~min}$, using the coupled process, the pollutants decreased in about $85 \%$, but in only $12 \mathrm{~min}$. This indicates that the process speed is increased 4 -fold, and the removal yield is also incremented twice.

As described previously, the dissolved metal provided by the electrochemical reactor is not enough to remove all the pollutants present in aqueous solution. Thus, the ozone contributes importantly to improving the pollutant removal. Some of the advantages of adding ozone during the EC process are the following: it provides good mixing through the reactor which improves the mass transfer, increases the oxidation of dissolved pollutants, and reduces the amount of produced sludge.

Table 1 presents recent works that describe the pollutant removal efficiency when the coupled EC-ozonation process is applied. It can be noticed that most of the studies used iron electrodes and ozone flow rate between 15 and $25 \mathrm{~mL}$ per min and that the color removal achieves nearly $100 \%$ in all cases. However, the COD or TOC could be reduced up to $90 \%$.

3.4. Mechanism. In addition to the improvement coming from the addition of the effects of the separated single treatment technology, the combined process involves an increased hydroxide radical production because transition metal ions $\left(\mathrm{Fe}^{+2}, \mathrm{Mn}^{+2}, \mathrm{Ni}^{+2}, \mathrm{Co}^{+2}, \mathrm{Cd}^{+2}, \mathrm{Cu}^{+2}, \mathrm{Ag}^{+}\right.$, and $\mathrm{Zn}^{+2}$ ) work as catalysts in the homogeneous liquid phase for the degradation of organic pollutants in wastewater. During the combined process, the metal ion established the rate of reaction in the degradation system and the efficiency of ozone application.

The most accepted mechanisms for which the metal ions accelerate the decomposition of ozone to generate hydroxyl radical are shown in (10)-(12). The $\mathrm{Fe}^{2+}$ cation is used as example in the well-known Fenton process. This mechanism helps to explain the synergistic effect of the combination of both technologies and the resulting high efficiencies [28]:

$$
\begin{aligned}
\mathrm{Fe}^{2+}+\mathrm{O}_{3} & \longrightarrow(\mathrm{FeO})^{2+}+\mathrm{O}_{2} \\
\mathrm{FeO}^{2+}+\mathrm{H}_{2} \mathrm{O} & \longrightarrow \mathrm{Fe}^{3+}+\mathrm{HO}^{\cdot}+\mathrm{OH}^{-} \\
\mathrm{FeO}^{2+}+\mathrm{Fe}^{2+}+2 \mathrm{H}^{+} & \longrightarrow 2 \mathrm{Fe}^{3+}+\mathrm{H}_{2} \mathrm{O}
\end{aligned}
$$

To explain why there is no $100 \%$ of COD removal, it is necessary to remember that degradation processes that involved oxidants, despite their high reactivity and low selectivity, normally also produce refractory final products. 


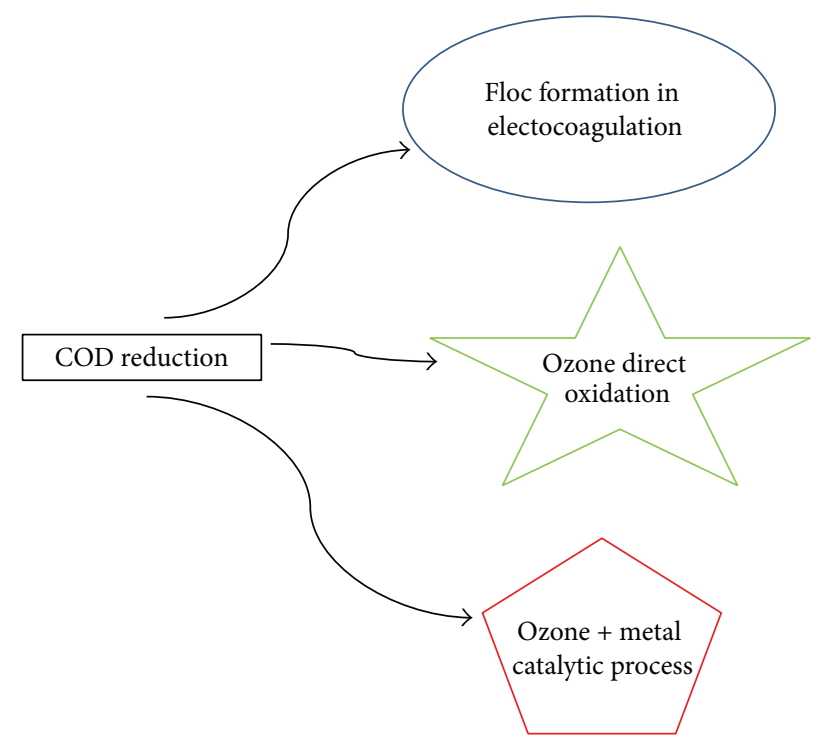

FIGURE 5: Schematic illustration of all mechanisms that takes place in the coupled EC-ozonation process.

These refractory carbon compounds are usually composed of small carboxylic acids, such as formic, succinic, oxalic, and acetic. They are refractory in nature and their final degradation in $\mathrm{CO}_{2}$ and water could be prohibited [29].

The low molecular weight carboxylic acids could react with the hydroxyl radicals in four different ways: (a) reactions involving cleavage of the $\mathrm{O}-\mathrm{H}$ bond, (b) attack by a nucleophile on the $\mathrm{C}-\mathrm{O}$ bond, (c) decarboxylation, and (d) attack on R-carbon. Only the attack to the $\mathrm{C}-\mathrm{O}$ bond could generate reactions that break the parent acid into compounds with lower molecular mass and finally into $\mathrm{CO}_{2}$ and water. Several studies have shown that the oxidative refractoriness of low molecular weight aliphatic acids follows the order: acetic acid $>$ propionic acid $>$ formic acid $>$ oxalic acid $>$ glyoxylic acid [30].

Finally, Figure 5 illustrates all the mechanisms involved in the EC-ozonation process.

\section{Conclusions}

(i) EC and ozonation processes alone reduce the COD content in complex industrial wastewater up to $50 \%$ in an hour of treatment.

(ii) Coupled electrochemical-ozone process is much more effective in a shorter period of time.

(iii) Coupling both processes results in a synergy, which reduces the COD by $88 \%$ in only $12 \mathrm{~min}$.

(iv) There are almost no differences in the performance of coupled EC-ozonation process, regardless of the used metal cation.

(v) This process could have a wide application in the treatment of wastewater treatment, since it is a simple and efficient procedure. Nevertheless, an ulterior analysis in the costs for an actual successful application is necessary.

\section{Conflict of Interests}

The authors declare that they have no conflict of interests.

\section{Acknowledgments}

The authors wish to acknowledge the support given by the Consejo Nacional de Ciencia y Tecnología (CONACYT) in Project 153828 that is greatly appreciated.

\section{References}

[1] G. Roa-Morales, E. Campos-Medina, J. Aguilera-Cotero, B. Bilyeu, and C. Barrera-Díaz, "Aluminum electrocoagulation with peroxide applied to wastewater from pasta and cookie processing," Separation and Purification Technology, vol. 54, no. 1, pp. 124-129, 2007.

[2] L. J. J. Janssen and L. Koene, "The role of electrochemistry and electrochemical technology in environmental protection," Chemical Engineering Journal, vol. 85, no. 2-3, pp. 137-146, 2002.

[3] T.-P. Moisés, B.-H. Patricia, C. E. Barrera-Díaz, R.-M. Gabriela, and R. Natividad-Rangel, "Treatment of industrial effluents by a continuous system: electrocoagulation-activated sludge," Bioresource Technology, vol. 101, no. 20, pp. 7761-7766, 2010.

[4] C. Barrera-Díaz, G. Roa-Morales, L. Ávila-Córdoba, T. PavónSilva, and B. Bilyeu, "Electrochemical treatment applied to food-processing industrial wastewater," Industrial and Engineering Chemistry Research, vol. 45, no. 1, pp. 34-38, 2006.

[5] C. Barrera-Díaz, B. Frontana-Uribe, and B. Bilyeu, "Removal of organic pollutants in industrial wastewater with an integrated system of copper electrocoagulation and electrogenerated $\mathrm{H}_{2} \mathrm{O}_{2}$," Chemosphere, vol. 105, pp. 160-164, 2014.

[6] O. T. Can, M. Kobya, E. Demirbas, and M. Bayramoglu, "Treatment of the textile wastewater by combined electrocoagulation," Chemosphere, vol. 62, no. 2, pp. 181-187, 2006.

[7] P. K. Holt, G. W. Barton, M. Wark, and C. A. Mitchell, "A quantitative comparison between chemical dosing and electrocoagulation," Colloids and Surfaces A: Physicochemical and Engineering Aspects, vol. 211, no. 2-3, pp. 233-248, 2002.

[8] K. Rajeshwar and J. Ibañez, Environmental Electrochemistry: Fundamentals and Applications in Pollution Abatement, Academic Press, New York, NY, USA, 1997.

[9] C. Barrera-Díaz, B. Bilyeu, G. Roa, and L. Bernal-Martinez, "Physicochemical aspects of electrocoagulation," Separation and Purification Reviews, vol. 40, no. 1, pp. 1-24, 2011.

[10] H. S. Peavy, D. R. Rowe, and G. Tchobanoglous, Environmental Engineering, McGraw-Hill, New York, NY, USA, 1985.

[11] C. Tsouris, D. W. DePaoli, J. T. Shor, M.-C. Z. Hu, and T.-Y. Ying, "Electrocoagulation for magnetic seeding of colloidal particles," Colloids and Surfaces A: Physicochemical and Engineering Aspects, vol. 177, no. 2-3, pp. 223-233, 2001.

[12] C. Y. Hu, S. L. Lo, W. H. Kuan, and Y. D. Lee, "Removal of fluoride from semiconductor wastewater by electrocoagulationflotation," Water Research, vol. 39, no. 5, pp. 895-901, 2005.

[13] M. I. Aguilar, J. Sáez, M. Lloréns et al., "Improvement of coagulation-flocculation process using anionic polyacrylamide as coagulant aid," Chemosphere, vol. 58, no. 1, pp. 47-56, 2005. 
[14] R. G. Casqueira, M. L. Torem, and H. M. Kohler, “The removal of zinc from liquid streams by electroflotation," Minerals Engineering, vol. 19, no. 13, pp. 1388-1392, 2006.

[15] J. G. Ibanez, M. M. Singh, and Z. Szafran, "Laboratory experiments on electrochemical remediation of the environment. Part 4: color removal of simulated wastewater by electrocoagulationelectroflotation," Journal of Chemical Education, vol. 75, no. 8, pp. 1040-1041, 1998.

[16] P. K. Holt, G. W. Barton, and C. A. Mitchell, "Deciphering the science behind electrocoagulation to remove suspended clay particles from water," Water Science and Technology, vol. 50, no. 12, pp. 177-184, 2004.

[17] P. Cañizares, M. Hernández-Ortega, M. A. Rodrigo, C. E. Barrera-Díaz, G. Roa-Morales, and C. Sáez, "A comparison between conductive-diamond electrochemical oxidation and other advanced oxidation processes for the treatment of synthetic melanoidins," Journal of Hazardous Materials, vol. 164, no. 1, pp. 120-125, 2009.

[18] M. Hernández-Ortega, T. Ponziak, C. Barrera-Díaz, M. A. Rodrigo, G. Roa-Morales, and B. Bilyeu, "Use of a combined electrocoagulation-ozone process as a pre-treatment for industrial wastewater," Desalination, vol. 250, no. 1, pp. 144-149, 2010.

[19] L. A. Bernal-Martínez, C. Barrera-Díaz, C. Solís-Morelos, and R. Natividad, "Synergy of electrochemical and ozonation processes in industrial wastewater treatment," Chemical Engineering Journal, vol. 165, no. 1, pp. 71-77, 2010.

[20] T. Zhang, W. Li, and J.-P. Croué, "A non-acid-assisted and nonhydroxyl-radical-related catalytic ozonation with ceria supported copper oxide in efficient oxalate degradation in water," Applied Catalysis B: Environmental, vol. 121, pp. 88-94, 2012.

[21] L. A. Bernal-Martínez, C. Barrera-Díaz, R. Natividad, and M. A. Rodrigo, "Effect of the continuous and pulse in situ iron addition onto the performance of an integrated electrochemicalozone reactor for wastewater treatment," Fuel, vol. 110, pp. 133$140,2013$.

[22] C. Barrera-Díaz, L. A. Bernal-Martínez, R. Natividad, and J. M. Peralta-Hernández, "Synergy of electrochemical $/ \mathrm{O}_{3}$ process with aluminum electrodes in industrial wastewater treatment," Industrial \& Engineering Chemistry Research, vol. 51, no. 27, pp. 9335-9342, 2012.

[23] American Public Health Association (APHA), American Water Works Association (AWWA), and WPCF, Standard Methods for the Examination of Water and Wastewater Procedures, APHA, AWWA, WPCF, 1989.

[24] I. Puigdomenech, Hydrochemical Equilibrium Constants Database (MEDUSA), Royal Institute of Technology, Stockholm, Sweden, 1997.

[25] D. Ghernaout, "Advanced oxidation phenomena in electrocoagulation process: a myth or a reality?" Desalination and Water Treatment, vol. 51, no. 40-42, pp. 7536-7554, 2013.

[26] M. Y. A. Mollah, R. Schennach, J. R. Parga, and D. L. Cocke, "Electrocoagulation (EC) - science and applications," Journal of Hazardous Materials, vol. 84, no. 1, pp. 29-41, 2001.

[27] R. Andreozzi, V. Caprio, A. Insola, and R. Marotta, "Advanced oxidation processes (AOP) for water purification and recovery," Catalysis Today, vol. 53, no. 1, pp. 51-59, 1999.

[28] C. E. Barrera-Díaz, G. Roa-Morales, P. B. Hernández, C. M. Fernandez-Marchante, and M. A. Rodrigo, "Enhanced electrocoagulation: new approaches to improve the electrochemical process," Journal of Electrochemical Science and Engineering, vol. 4, no. 4, pp. 285-296, 2014.
[29] A. T. Quitain, M. Faisal, K. Kang, H. Daimon, and K. Fujie, "Low-molecular-weight carboxylic acids produced from hydrothermal treatment of organic wastes," Journal of Hazardous Materials, vol. 93, no. 2, pp. 209-220, 2002.

[30] R. V. Shende and J. Levee, "Wet oxidation kinetics of refractory low molecular mass carboxylic acids," Industrial and Engineering Chemistry Research, vol. 38, no. 10, pp. 3830-3837, 1999.

[31] P. Asaithambi, M. Susree, R. Saravanathamizhan, and M. Matheswaran, "Ozone assisted electrocoagulation for the treatment of distillery effluent," Desalination, vol. 297, pp. 1-7, 2012.

[32] V. Orescanin, R. Kollar, and K. Nad, "The application of the ozonation/electrocoagulation treatment process of the boat pressure washing wastewater," Journal of Environmental Science and Health-Part A: Toxic/Hazardous Substances and Environmental Engineering, vol. 46, no. 12, pp. 1338-1345, 2011.

[33] S. Song, J. Yao, Z. He, J. Qiu, and J. O. Chen, "Effect of operational parameters on the decolorization of C.I. Reactive Blue 19 in aqueous solution by ozone-enhanced electrocoagulation," Journal of Hazardous Materials, vol. 152, no. 1, pp. 204-210, 2008.

[34] S. Song, Z. He, J. Qiu, L. Xu, and J. Chen, “Ozone assisted electrocoagulation for decolorization of C.I. Reactive Black 5 in aqueous solution: an investigation of the effect of operational parameters," Separation and Purification Technology, vol. 55, no. 2, pp. 238-245, 2007.

[35] Z. Q. He, S. Song, J. P. Qiu et al., "Decolorization of C.I. Reactive Yellow 84 in aqueous solution by electrocoagulation enhanced with ozone: influence of operating conditions," Environmental Technology, vol. 28, no. 11, pp. 1257-1263, 2007. 

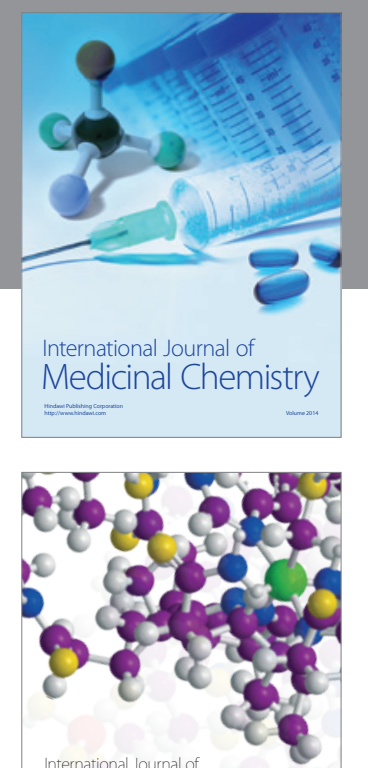

\section{Carbohydrate} Chemistry

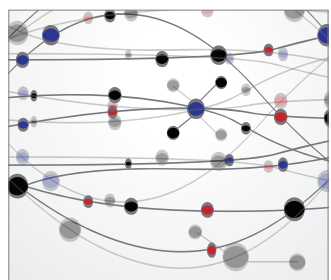

The Scientific World Journal
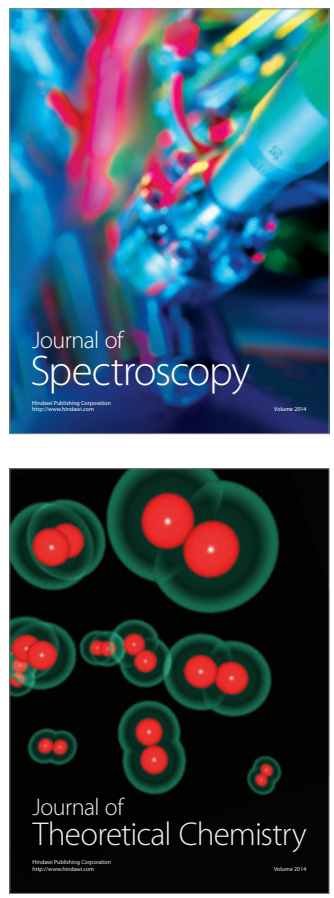
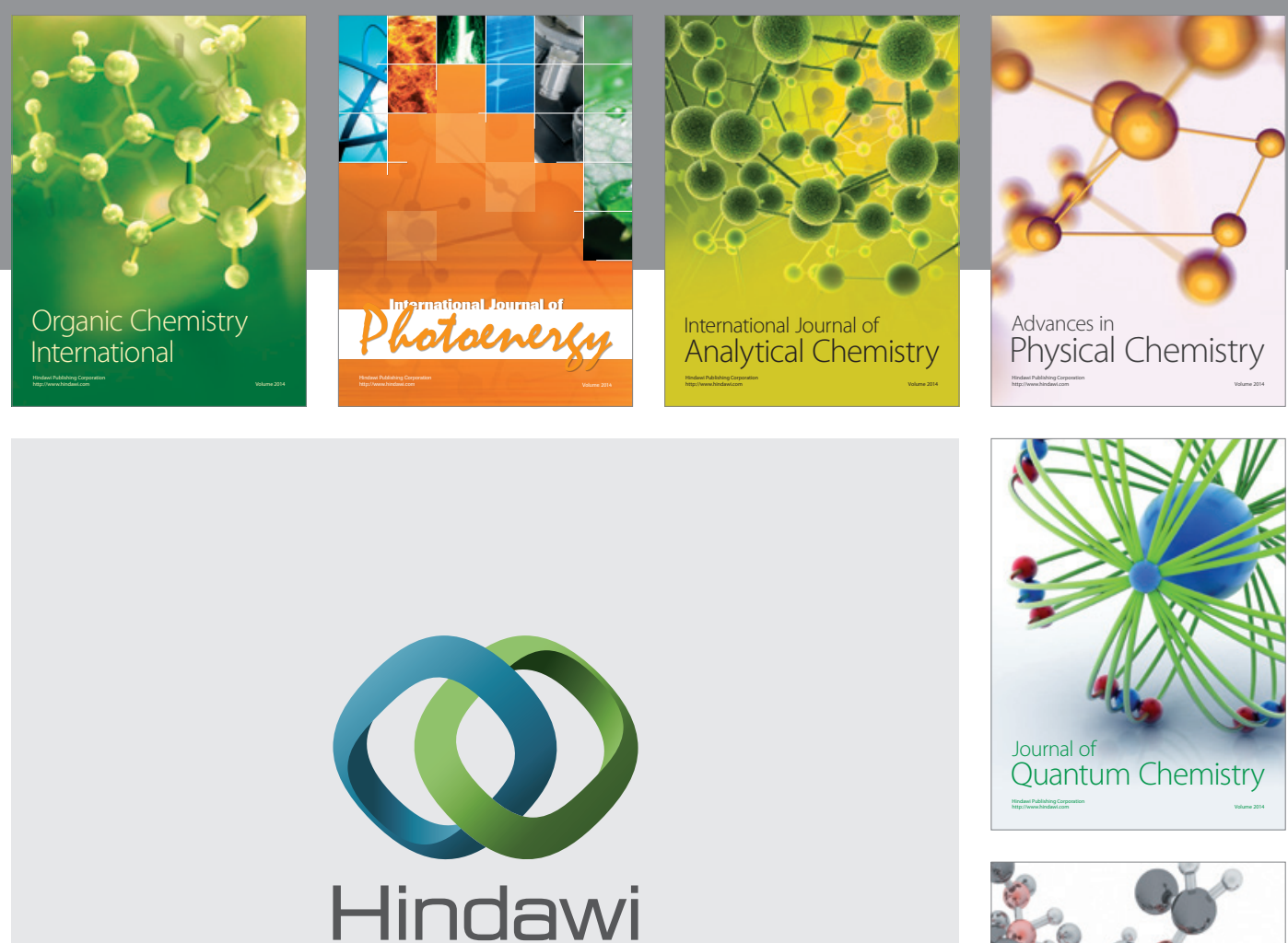

Submit your manuscripts at

http://www.hindawi.com

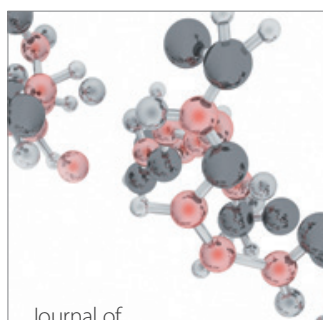

Analytical Methods

in Chemistry

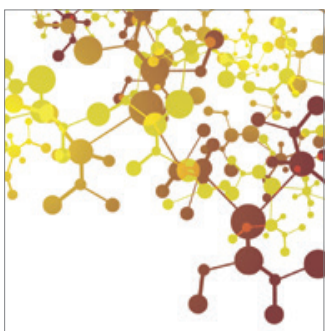

Journal of

Applied Chemistry

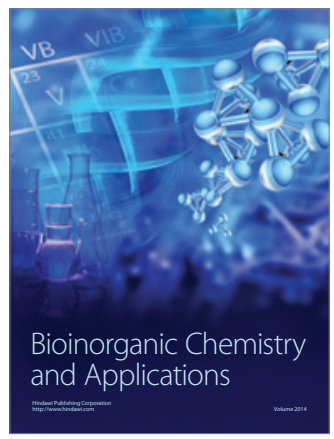

Inorganic Chemistry
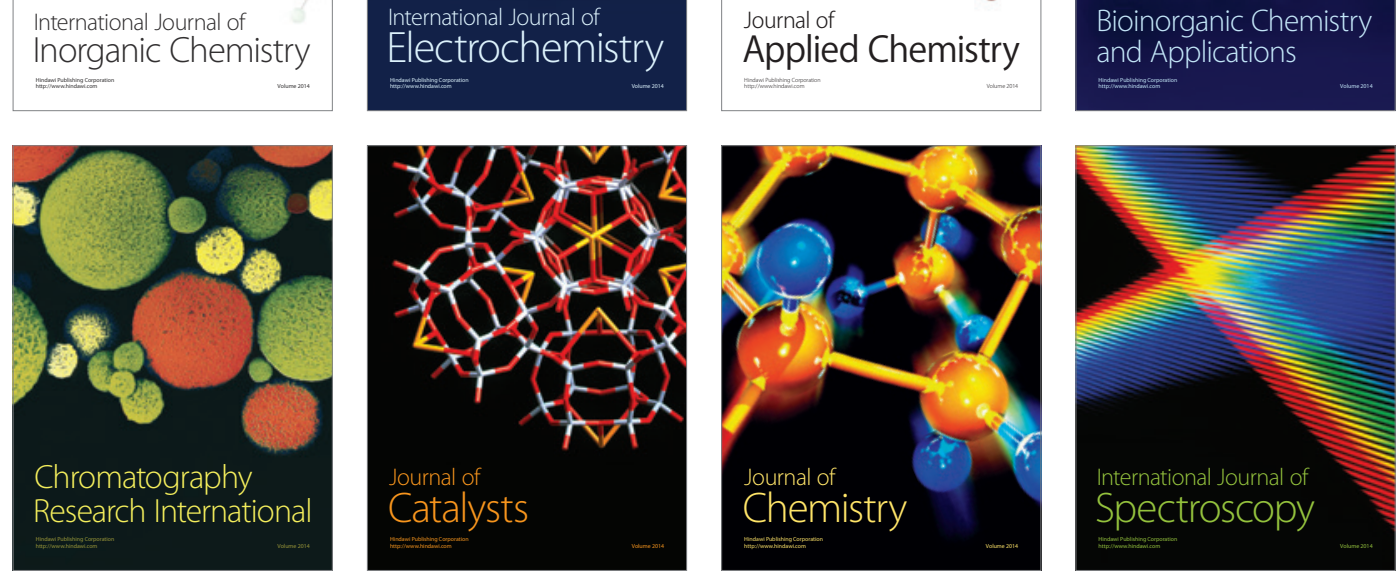